\title{
Nawoja Mikołajczak-Matyja
}

Instytut Językoznawstwa, Uniwersytet im. Adama Mickiewicza w Poznaniu

\section{Kohiponimia jako relacja z pogranicza kategorii opozycji semantycznej. Perspektywa użytkownika języka polskiego: badanie psycholingwistyczne}

\section{Wstęp}

Jedną z ważniejszych cech językoznawstwa drugiej połowy wieku XX i początku XXI jest rosnący wpływ koncepcji formułowanych w ramach podejścia kognitywnego. Należy do nich teoria prototypów pojęciowych, która stanowi obecnie także istotny element łączący rozważania z zakresu semantyki leksykalnej z badaniami nad odzwierciedleniem relacji semantyczno-leksykalnych w umyśle użytkownika języka. Od ostatnich dziesięcioleci ubiegłego stulecia zaczęły bowiem pojawiać się w językoznawstwie próby przedefiniowania relacji semantycznych w terminach założeń tej teorii, czyli próby interpretowania ich jako kategorii posiadających część centralną (prototyp) i część peryferyjną. Założenia dotyczące reprezentowania przez umysł wiedzy o świecie i wiedzy językowej w postaci kategorii o takiej strukturze są powszechne w psycholingwistyce i psychologii poznawczej od lat 70. XX wieku.

Zastosowanie teorii prototypów do rozważań nad relacją opozycji semantycznej ${ }^{1}$ ma wagę szczególną ze względu na rolę tej relacji w funkcjonowaniu

1 Termin „opozycja semantyczna” jest tu rozumiany jako ogólna nazwa relacji między dwoma wyrazami o znaczeniach przeciwnych, jak np. w pracach Johna Lyonsa i Davida Alana Cruse'a. Cruse stosuje termin „opozycja ogólna” (the general category of opposites [Cruse 1994: 178]) jako nazwę relacji obejmującej podrodzaje węższe (jak komplenimia, antonimia czy konwersja), ale bardziej szczegółowej niż „relacja niekompatybilności”. W innych swoich pracach Cruse używa terminu „opozycja” (opposition) wyłącznie w odniesieniu do relacji dwuczłonowych [np. Cruse 1995; 2000], podobnie jak Lyons w pracy Semantics. W polskim przekładzie książki Lyonsa angielski termin opposition (jako nazwa relacji dwuczłonowej) tłumaczony jest jako „przeciwstawienie”, a ogólniejszy termin contrast jako „opozycja” [por. Lyons 1984, t. 1: 270]. 
poznawczym i językowym. Uznaje się ją za poznawczo prymarną, a prymarność tę interpretuje się np. w takich psychologicznych terminach, jak: tendencja do kategoryzowania doświadczenia na bazie dychotomicznego kontrastu [Lyons 1977: 277], zdolność do uwydatniania różnic (tworzenia opozycji) jako ogólna cecha myślenia [McNeill 1997: 199] lub jego rdzeń [Cixious 1989: 91] czy istotność kontrastu binarnego dla organizacji procesów percepcji i poznania [np. Paradis, Willners 2011: 369; Cacciari i in. 2015: 95]. Opozycja semantyczna jest relacją opartą na ,różnicy w podobieństwie”. Ta jednoczesna bliskość i różnica znaczenia między elementami opozycji uważana jest za cechę wyróżniającą ją spośród innych relacji semantycznych i nadającą jej specyficzną tajemniczość czy nawet magię [Cruse 1995: 197; Muehleisen, Isono 2009: 2185]. Stanowi ona ważną właściwość budowy leksyki języków naturalnych oraz istotny czynnik organizacji tekstu i dyskursu [por. np.: Lyons 1977: 271; Cruse 1995: 197; Jones 2002: 8, Murphy 2003: 169; Davies 2012: 42; van de Weijer i in. 2014: 1].

Interpretacje opozycji w terminach teorii prototypów koncentrują się zazwyczaj na określeniu czynników wyznaczających centrum kategorii. Są to, poza binarnością, przede wszystkim takie cechy, jak: minimalność i zarazem inherentność różnicy znaczeniowej między członami pary, łatwość wyodrębnienia wymiaru różnicującego, diametralność i symetryczność, a także czynniki oparte na częstości współwystępowania w kontekstach (cechy wymieniane w różnej liczbie i różnych układach m.in. w pracach: Herrmann i in. 1979: 587; Mettinger 1994: 65; Cruse 1994: 179; 1995: 262; 2000: 167-168; Jones 2002: 7, 117; Murphy 2003: 170 i inne; Markowski 1986: 40)².

Przedmiotem zainteresowania w niniejszej pracy, stanowiącej teoretyczno-badawcze studium nad językiem współczesnym na przykładzie leksyki polskiej, są peryferyjne części kategorii opozycji. Jedno z podstawowych założeń teorii prototypów dotyczy płynności granic kategorii, czyli istnienia egzemplarzy granicznych, których przynależność do kategorii jest dyskusyjna [np. Rosch 1975: 192-233; Taylor 2001: 70 i inne]. Celem przedstawionych poniżej rozważań i badań jest próba określenia, jaki rodzaj materiału leksykalnego buduje pogranicze relacji, oraz dostarczenie przykładów opozycji pogranicznych w języku polskim.

2 Część tych cech, np. minimalny kontrast, bywa traktowana przez niektórych autorów jako definicyjna dla relacji antonimii, rozumianej wąsko (jak w pracy Andrzeja Markowskiego [1986]) lub szeroko (jak np. w pracy Lynne M. Murphy [2003]). Problem stosowania terminu ,antonimia” i zakresu relacji nazywanej w ten sposób wykracza poza ramy tego artykułu. 


\section{Kohiponimy jako materiał pogranicza kategorii opozycji} semantycznej: dane $\mathrm{z}$ analiz językoznawczych i z badań korpusowych Dane pochodzące $\mathrm{z}$ analiz językoznawczych, a także wyniki współczesnych badań korpusowych wskazują, że potencjalnie istotnym materiałem peryferyjnych i pogranicznych obszarów kategorii relacji opozycji semantycznej są pary kohiponimów pochodzących ze zbiorów wieloelementowych.

Kohiponimy to, najkrócej mówiąc, jednostki leksykalne będące hiponimami tego samego hiperonimu [Bańczerowski i in. 1982: 209]. Lyons precyzuje istotę relacji między kohiponimami jako różnicę między wbudowanymi określnikami wspólnego hiperonimu [Lyons 1984, t. 1: 283-284]. Relacja kohiponimii jest więc taką odmianą niekompatybilności znaczeniowej (wykluczania się znaczeń), w przypadku której istnieje wspólny (bliski) hiperonim jednostek niekompatybilnych. Niekompatybilne dla wyrazu kobieta moga być np. jednostki mężczyzna, krowa, drzewo, śrubokręt [przykłady z: Leech 1987: 92], ale jako kohiponim kobiety potraktujemy raczej jedynie pierwszy z nich, ze wspólnym bliskim hiperonimem czlowiek $^{3}$.

Kohiponimię w zbiorach wieloelementowych postrzega się niekiedy jako formalnie podobną do opozycji binarnej [Hurford i in. 2007: 136-137] lub jako ,antonimię niestopniowalną rozszerzoną do dwóch lub więcej terminów” [Jones 2002: 18, przeł. - N.M.M.].

Istnienie bliskiego hiperonimu wspólnego dla danych dwóch jednostek i tylko dla nich wskazuje różnicę między tymi kohiponimami, które można traktować jako przypadki niewątpliwej, silnej opozycji, a „zwykłymi” kohiponimami ze zbioru wieloelementowego. Przykładem dwóch jednostek silnie skontrastowanych są ręka i noga, ze wspólnym bliskim hiperonimem (ludzka) kończyna, mimo iż stanowią one także elementy większego zbioru hiponimów hiperonimu część ciała. Jako nieco słabsze, ale również wyraźne opozycje interpretuje się niekiedy pary wyłaniające się z małych zbiorów kohiponimicznych, takich jak nazwy pór roku czy kierunków geograficznych. Szczególnie dobrymi kandydatami są tu, odpowiednio, pary lato - zima oraz pótnoc potudnie i wschód - zachód. Względnie silna opozycyjność pary lato - zima wynika z faktu, że zawiera ona podstawowy kontrast cieply - zimny [Markowski 1986: 87; Cruse 1995: 260], który ma tutaj charakter symetryczny i diametralny, bo oparty na wspólnej cesze „ekstremalności temperatur” na

3 Zdaniem Cruse'a kohiponimami, tj. hiponimami tego samego hiperonimu mogą być także wyrazy, których znaczenia się nie wykluczają, np. królowa i matka jako hiponimy wyrazu kobieta. Dlatego relację między wyrażeniami o wykluczających się znaczeniach i posiadającymi bliski wspólny hiperonim określa jako niekompatybilność; opozycja binarna stanowi według niego podtyp niekompatybilności [Cruse 1995: 137; 2000: 166]. 
przeciwnych stronach skali [Lyons 1984: 276; Murphy 2003: 200] ${ }^{4}$. Przeciwstawnikami diametralnymi, w tym przypadku o charakterze kierunkowym, są też wymienione wyżej pary nazw kierunków geograficznych [Lyons 1984: 276]. Kontrast ten może zostać wzmocniony dzięki czynnikom kulturowym, w tym politycznym (np. wojna secesyjna Północ-Południe w USA, kultury Wschodu i Zachodu).

Spotyka się pogląd, że silnymi opozycjami są także pary ze zbiorów 3-elementowych typu stały - plynny - gazowy lub zwierze - roślina - minerat [Murphy 2003: 178]. Większe kontrowersje budzi klasyfikowanie jako oczywistych opozycji par wyłaniających się ze zbiorów kohiponimicznych o większej, nieokreślonej (niekiedy nieskończonej) liczbie elementów, jak nazwy barw, kształtów, zbiorów nazw zwierząt, np. ssaków, oraz artefaktów, np. mebli. Markowski [1986: 84-86] nie traktuje takich przypadków (np. smaków, zapachów, kształtów) jako wyraźnych opozycji, ze względu na brak minimalnej różnicy i wyraźnej zasady porządkującej relację w takich parach. Cruse podkreśla różnicę między relacją opozycji a „zwykłymi” przypadkami niekompatybilności, takimi jak kot-pies [Cruse 1995: 257]. Bardziej liberalne stanowisko przyjmują autorzy podkreślający rolę realnych użyć i kontekstu w określaniu granic relacji semantycznych. Murphy [2003: 177, 187] proponuje uznać za przykłady opozycji kanonicznych (choć nie prototypowych) pary stót-krzesło i kot-pies, podkreślając częstość współwystępowania ich członów w kontekstach. Dla pary kot - pies wskazuje liczne podobieństwa (np. nazwy z poziomu podstawowego, denotujące zwierzęta czworonożne, futerkowe, oswojone, o podobnym rozmiarze, trzymane w domu, ale nie w klatkach), które mogą być podstawą traktowania relacji między członami jako opartej na „różnicy w podobieństwie”. Z kolei Jones jako przykład kohiponimów mających „,inherentny potencjał kontrastowy" [Jones 2002: 51] wskazuje nazwy liczb całkowitych, zwłaszcza o niskich wartościach. Prawdopodobieństwo traktowania pary kohiponimów jako stanowiącej wyraźną opozycję jest większe, gdy znaczenie jej członów zawiera jakąś łatwą do wyodrębnienia opozycję podstawową. Ten właśnie czynnik wzmacnia opozycję pary lato - zima, a pozwala na kwalifikowanie jako dość silnych również par typu strych - piwnica (nazwy części budynku, zawierające kontrast przestrzenny góra - dót) lub kotyska - grób (nazwy miejsc do leżenia, z kontrastem czasowym) [Cruse 1995: 225].

4 Zdaniem Cruse'a [1995: 260] para ta byłaby postrzegana jako opozycyjna, nawet gdyby zaburzono jej geometryczną podstawę przez wprowadzenie piątej pory roku. Natomiast pozostałe pary w tym zbiorze nie są tak wyraźnie skontrastowane: według Lyonsa wiosna przeciwstawia się równie wyraźnie latu i zimie, jak przeciwstawnikowi diametralnemu jesień [Lyons 1984: 276]. 
O wyłanianiu się wyraźnie skontrastowanych par z większych zbiorów kohiponimów decydują również warunki geograficzne, społeczne, historyczne i kulturowe. Przykładem istotnym i trwałym w naszej kulturze może być niebo - piekło (para zawiera więcej niż jeden prostszy kontrast, np. góra-dót, dobry - zły, światto - ciemność), społeczny przykład współczesny to matżeństwo - zwiazek partnerski, a geograficzny to np. góra - dolina dla Polaka, ale góra - ocean dla Japończyka [por. Cruse 1995: 225; Hofmann 1993 za: Murphy 2003: 213; Okuniewska 2004: 134]. Tendencje do klasyfikowania zjawisk w pary czy grupy przez dawne i współczesne społeczności podkreślane są w pracach z dziedziny antropologii kulturowej [np. Lloyd 1966: 15-171]. Tendencje te dotyczą m.in. gatunków zwierząt, roślin, rodzajów pożywienia i różnych artefaktów. Na przykład Claude Lévi-Strauss przez analizę struktury mitów Indian południowoamerykańskich ukazał kulturową rolę zarówno opozycji typu człowiek - określony gatunek zwierzęcia (np. człowiek-małpa, czlowiek-jaguar, czlowiek-ptak, czlowiek-świnia), jak i skontrastowanych w mitach par różnych gatunków zwierząt (np. matpa - jaguar, jaguar - jeleń, jaszczurka - krokodyl, koliber - gołab) [Lévi-Strauss 2010: 89, 99, 136, 144, 204, 205 i inne].

Rolę par opozycji z wieloelementowych zbiorów kohiponimicznych i konieczność ich badania ukazują w ostatnich dziesięcioleciach wyniki badań korpusowych. W pracy Mettingera [1994], jednym z pierwszych i bardziej znaczących opracowań tego rodzaju (na bazie tekstów powieści angielskojęzycznych), stwierdzono wykorzystywanie w komunikatach par opozycji zarówno systemowych (jak szeroki - wąski lub miłość - nienawiść), opartych na kontraście ściśle semantycznym, jak i niesystemowych. W parach niesystemowych kontrast ujawniany jest wyłącznie w określonych kontekstach, a próba ich interpretacji wymaga uciekania się do wiedzy encyklopedycznej i pragmatycznej. Wśród różnych przykładów opozycji niesystemowych pojawiają się m.in. takie pary, jak głowa - ogon, wyłaniające się z większych zbiorów kohiponimów [Mettinger 1994: 61, 83]. W pracy Jonesa [2002] analiza zdań z korpusu tekstów z czasopisma angielskojęzycznego ukazała znaczącą rolę stosowania silnych opozycji (np. szybki-wolny) w funkcji wskazywania lub uwydatniania kontrastu innej pary (funkcja określana jako ,ancillary antonymy"). Pary, których kontrast jest uwydatniany, Jones podzielił na osiem grup, i pięć z nich to pary wyłaniające się z wieloelementowych zbiorów kohiponimicznych. Dotyczą one odpowiednio: polityki (np. nazwy ideologii: komunizm - faszyzm), ludzi (np. nazwiska prezydentów danego kraju), geografii (np. nazwy miast), czasu (np. sześć miesięcy temu - dziś), kwantyfikacji (np. liczby: 40\%-45\%) [Jones 2002: 48-53]. Znacząca rola funkcji uwydat- 
niania kontrastów przez pary silnych opozycji, a zarazem wysoka częstość pojawiania się opozycji kontekstowych (tj. uwydatnianych w określonym kontekście) zostały potwierdzone w licznych późniejszych badaniach, np. w badaniach korpusów zbudowanych z tekstów mówionych [Jones 2006: 203], tekstów języka dzieci i języka skierowanego do dzieci [Jones 2007: 1118], tekstów w językach innych niż angielski, np. szwedzkim [Murphy i in. 2009: 2180] czy japońskim [por. Muehleisen, Isono 2009: 2192]. W pracy Murphy i in. [2015: 235-237] wśród par o kontraście uwydatnianym w kontekstach (przez silną parę opozycji) dokonano rozróżnienia na kohiponimy i kohiponimy dalsze (czyli takie, których wspólny hiperonim był więcej niż jeden poziom wyżej w hierarchii). W badaniach korpusowych przeprowadzonych przez Lobanovą i in. zaproponowano, aby pary kohiponimów, takie jak np. rzeczywistość utopia lub śródmieście - przedmieścia, które funkcjonują w kontekstach tak jak pary antonimiczne, traktować jako podtyp relacji antonimii [Lobanowa in. 2010: 20, 44-48].

\section{Rozważania metodologiczne nad badaniem realności psychologicznej opozycyjnego charakteru kohiponimii}

Przedstawione wyżej dane z badań korpusowych dowodzą, że nadawcy analizowanych komunikatów pisemnych lub ustnych potrafili znaleźć kontrast między dwoma elementami zbioru kohiponimów i uwypuklić go w kontekście, przy użyciu odpowiednich struktur gramatycznych. Dane tego rodzaju stanowią dobrą podstawę założenia o sensowności badań nad określeniem roli takich par w językowej wiedzy użytkownika języka, a w szczególności nad możliwością ich postrzegania (przez użytkownika) jako rzeczywistych opozycji. Silnych dowodów na temat stopnia psychologicznej realności opozycyjności relacji kohiponimii należy szukać w danych uzyskanych z badań psycholingwistycznych ${ }^{5}$ wymagających od respondentów nie tylko aktywizacji danego połączenia jednostek leksykalnych, ale także świadomości jego rodzaju ${ }^{6}$.

Najbardziej klasyczne metody badań psycholingwistycznych - analiza skojarzeń swobodnych i pomyłek językowych - mogą dowodzić istotnej roli

5 Wydaje się, że dane z antropologii kulturowej nie mogą odgrywać takiej roli. Lévi-Strauss, przedstawiając swoje analizy mitów Indian południowoamerykańskich (por. poprzedni paragraf), twierdził, że przedstawiciele danej społeczności raczej nie postrzegają systemów relacji ukrytych w mitach. Jego zdaniem celem analizy jest pokazanie, ,jak mity myślą się w ludziach", a nie jak ludzie myślą [Lévi-Strauss 2010: 19].

6 Próbę uporządkowania podstawowych metod psycholingwistycznych na „kontinuum świadomości" powiązań między aktywizowanymi jednostkami zawiera praca: Mikołajczak-Matyja 2008: 105-107. 
połączeń kohiponimicznych w strukturze wiedzy językowej użytkownika. $\mathrm{W}$ polskich normach skojarzeniowych zarówno z lat 60. ubiegłego wieku, jak i z początku obecnego reakcja noga stanowi skojarzenie dominujące na hasło ręka, krzesło zostało podane jako reakcja dominująca na stół przez 30,2\% osób w badaniach z lat 60 . XX wieku i jako reakcja o randze II przez $24,4 \%$ respondentów w badaniu z początku wieku XXI, a stót jako dominująca reakcja na krzesto - przez 18,8\% w normach starszych i nowszych [Kurcz 1976: 254, 256, 257; Łobacz, Mikołajczak-Matyja 2002: 177, 178, 179]. Kohiponimy stanowiły około $75 \%$ ze zbioru 181 pomyłek językowych o charakterze substytucji rzeczownikowych, klasyfikowanych przez Garretta [Garrett 1992 za: Murphy 2003: 51]. Wyniki takie nie dowodzą jednak uznawania aktywizowanych automatycznie połączeń za związki o charakterze opozycji, podobnie jak nie będą tego dowodziły wyniki badań nad torowaniem czy generalizacją semantyczną, w których wpływ zaktywizowanej relacji semantycznej na określone reakcje nie wiąże się z koniecznością uświadamiania sobie jej rodzaju.

Silniejszy dowód opozycyjności kohiponimów można by uzyskać $\mathrm{z}$ badań nad oceną podobieństwa różnych relacji semantycznych, przeprowadzonych np. metodą sortowania podanych par lub metodą analogii (spośród kilku podanych par wyrazów należy wybrać taką, której elementy są połączone relacją analogiczną do relacji w parze wyjściowej). Badania Rogera Chaffina i Douglasa Hermanna [1987: 228] wykazują np. grupowanie przez osoby badane par typu grabie - widelec razem z parami antonimicznymi. Para taka, nie połączona nawet bliskim związkiem kohiponimii (człony należą do różnych podkategorii ogólnej kategorii PRZYRZĄD) może być traktowana przez respondentów jako opozycyjna pod wpływem sytuacji eksperymentalnej, w której materiałem są wyłącznie pary leksemów podawane do grupowania. Oczywiście, stopień uświadamiania sobie przez respondentów stosowanych kryteriów podobieństwa relacji jest prawdopodobnie zróżnicowany indywidualnie.

Do badania stopnia realności psychologicznej interpretowania relacji kohiponimii jako opozycyjnej najbardziej przydatne wydają się metody, w których badanym poleca się explicite: poszukiwanie elementów związanych z bodźcem określoną relacją semantyczną, nazywanie relacji między podanymi wyrazami lub ocenę sensowności nazywania jej w określony sposób. Można zatem do nich zaliczyć skojarzenia kierowane oraz ocenę siły opozycji danej pary wyrażeń na skali lub na zasadzie decyzji typu tak-nie. Wyniki badań prowadzonych w ostatnich dziesięcioleciach z użyciem takich metod wskazały bardziej i mniej typowe przykłady relacji opozycji semantycznej. Do klasycznych zalicza się badania Herrmanna i in. [1986] (na materiale 100 par wyrazów), w których jedna grupa respondentów oceniała na skali pięciopunktowej siłę opozycji pary 
(najwyższą średnią ocenę otrzymała para maximize - minimize, a najniższą średnią otrzymały m.in. pary courageous - diseased i daring - sick), a druga grupa podejmowała decyzję, czy para ta stanowi parę antonimiczną. Stwierdzono bardzo wysoką korelację między wynikami obu zadań [Herrmann i in. 1986: 139, 148-150]. W nowszej pracy, Paradis i in. [2009], połączono test podawania antonimów $\mathrm{z}$ testem oceny: $\mathrm{w}$ teście oceny 50 rodzimych użytkowników języka angielskiego oceniało 53 pary przymiotników stopniowalnych (były to pary antonimów o różnej sile, synonimów i pary niepowiązane semantycznie) na skali 11-stopniowej, odpowiadając na pytanie: ,how good is X-Y as a pair of opposites?" W teście skojarzeń kierowanych 50 (innych) respondentów uzupełniało pisemnie zdania typu: „The opposite of little is......”. W badaniu pierwszym uzyskano statystycznie istotne różnice między średnimi ocenami dla poszczególnych grup, a wyniki drugiego pozwoliły na uporządkowanie materiału badawczego według zróżnicowania uzyskanych odpowiedzi: od siedmiu przymiotników, dla których wszyscy badani podali tę samą reakcję jako opozycję semantyczną hasła, aż po wyraz, dla którego uzyskano najwyższą liczbę różnych reakcji (29) [Paradis i in. 2009: 397-398, 403-404]. Wyniki badania drugiego zostały także porównane $\mathrm{z}$ danymi korpusowymi (pozyskanymi z World Wide Web) we wcześniejszej pracy [Jones i in. 2007]. Ogólnie stwierdzono wysoki stopień korelacji między parami pozyskiwanymi w badaniu psycholingwistycznym a parami współwystępującymi w określonych, kontrastujących znaczenie konstrukcjach składniowych [Jones i in. 2007: 141].

W ostatnich latach przeprowadzono badanie neurolingwistyczne z użyciem wskaźnika ERP, a dokładniej amplitudy N400. Badani (użytkownicy języka szwedzkiego) podejmowali decyzję, czy elementy prezentowanej pary (szwedzkich) przymiotników stanowią opozycję semantyczną. Wykorzystano pary przymiotnikowych opozycji o różnej sile i pary przymiotników niepowiązanych semantycznie. Stwierdzono istotną statystycznie różnicę wysokości amplitudy N400 między poszczególnymi grupami par (opozycjami silnymi, słabymi, parami niepowiązanymi) [van de Weijer i in. 2014: 2-3].

Do rozpoczęcia weryfikowania stopnia realności psychologicznej określonej relacji najbardziej nadaje się metoda skojarzeń kierowanych. Dostarcza ona bowiem materiału do wykorzystania w badaniach prowadzonych innymi metodami.

\section{Cel i metoda badania}

Zasadniczym celem badania przedstawionego poniżej była psycholingwistyczna weryfikacja założenia o znaczącej roli kohiponimii jako relacji z pogranicza kategorii opozycji semantycznej, sformułowanego na bazie analiz języko- 
znawczych i wyników badań korpusowych zaprezentowanych w paragrafie 2 . O wyborze metody skojarzeń kierowanych (por. paragraf 3) zadecydowała, oprócz argumentów przedstawionych w paragrafie 3, możliwość otrzymania odpowiedzi na dwa dodatkowe pytania:

a) w przypadku uzyskania odpowiedzi stanowiących kohiponim bodźca: jakie cechy decydują o wyodrębnieniu określonej pary ze zbioru wieloelementowego?

b) w przypadku uzyskania odpowiedzi, które nie stanowią kohiponimów bodźców: jakie są inne mechanizmy budowania pogranicza relacji opozycji?

Odpowiedzi na oba pytania mogą dostarczyć cennych danych na temat sposobu rozumienia relacji przeciwieństwa znaczeniowego przez użytkowników języka.

Zatem cel zrealizowano przez prezentowanie badanym listy słów-haseł, z następującą instrukcją:

Poniżej znajduje się szereg wyrazów. Przy każdym z nich napisz inny wyraz, który Twoim zdaniem ma znaczenie maksymalnie przeciwne w stosunku do podanego. Wybrany wyraz nie może być spokrewniony z tym podanym pod względem budowy - nie twórz wyrazów przez dodanie nie-, anty-, bez- itp. Dobrze się zastanów nad wyborem wyrazów, zadawaj sobie pytanie: co jest przeciwieństwem...? Jeśli nie możesz wybrać jednego wyrazu, napisz dwa, ale nie więcej.

Założono, że respondent wybierze odpowiedź, która w momencie badania i w wyniku percepcji hasła zostanie przez niego uznana za najbardziej zgodną z instrukcją. W poleceniu zastosowano terminy „przeciwieństwo”, „znaczenie przeciwne" jako najbardziej ogólne i neutralne, a zatem najwłaściwsze w badaniu sposobu odzwierciedlenia relacji w umyśle przeciętnego użytkownika języka ${ }^{7}$. Instrukcja zawiera dodatkowe ograniczenie, sformułowane jako zakaz podawania wyrazów spokrewnionych morfologicznie z hasłem. Celem ograniczenia było odkrywanie relacji między wyrazami istniejącymi, a nie potencjalnymi (kosztem pewnych aspektów wiedzy ogólnej na temat pojęcia opozycji).

7 Termin „opozycja” ma charakter bardziej terminologiczny, a ponadto jest wyraźnie polisemiczny i może budzić dodatkowe skojarzenia na skutek wzajemnego oddziaływania poszczególnych znaczeń (w tym znaczenia politycznego, być może dziś najłatwiej aktywizowanego przez użytkownika języka polskiego). 


\section{Materiał badawczy i respondenci}

Materiał poddany analizom w obecnej pracy stanowią 24 rzeczowniki z pól semantycznych stanowiących częsty przedmiot analiz i badań leksykalno-semantycznych oraz psycholingwistycznych: po osiem nazw roślin, zwierząt i artefaktów. W grupie roślin znalazły się: dąb, sosna, fiołek, pokrzywa, kapusta, żyto, mech, paproć, a zatem nazwy roślin silnie różnicowanych w taksonomiach naukowych, należące także do różnych kategorii morfologiczno-funkcjonalnych i potocznych, takich jak rośliny dzikie i uprawne, drzewa (liściaste i iglaste ${ }^{8}$ ), kwiaty, chwasty, warzywa, zboża, runo leśne. Grupę nazw zwierząt stanowią rzeczowniki: wróbel, pingwin, zebra, krowa ${ }^{9}$, źótw, ropucha, meduza, pszczoła, których denotaty również są silnie różnicowane $\mathrm{w}$ taksonomiach naukowych (od ssaków, poprzez ptaki, gady, płazy, po bezkręgowe ${ }^{10}$ ), w tym zwierzęta dzikie i hodowane oraz żyjące w różnych warunkach klimatycznych. Grupa artefaktów ogranicza się do obiektów stanowiących wyposażenie domu, z funkcją wykorzystania powierzchni (przechowywanie/przebywanie na) lub wnętrza (przechowywanie w). Składa się na nią podgrupa z kategorii mebli: szafa, pótka, tóżko, fotel oraz podgrupa mniejszych obiektów o funkcji przechowywania w/na: wazon, szkatułka, popielniczka, taca. Ogólnie, wybrano jednostki, które mogą być klasyfikowane jako należące do grup wyznaczonych przez różne kryteria (i o różnie ocenianej ,czystości” hiponimii): do grup rodzajów naturalnych, do grup opartych na funkcji i pochodzeniu, jak np. zioła, chwasty i warzywa, oraz do grup kolektywno-funkcjonalnych, jak meble czy naczynia [por. m.in. analizy w pracach: Wierzbicka 1999: 92-95; Grochowski 1993: 60-75; Cruse 2002: 17]. Dodatkowym kryterium doboru było zróżnicowanie łatwości znalezienia kohiponimów z bliskim wspólnym hiperonimem (łatwiej znaleźć taki kohiponim np. dla słów wróbel, sosna, łóżko niż, odpowiednio, dla słów meduza, mech, popielniczka).

Powyższe 24 rzeczowniki stanowiły część większego materiału 100 haseł z różnych pól leksykalno-semantycznych ${ }^{11}$, podzielonych na cztery wersje ankiety po 25 jednostek każda. W każdej wersji znalazło się sześć z 24 analizowanych tu jednostek, przy czym nazwy z dających się wydzielić mniejszych

8 Celem wyboru pary drzew sosna i dąb było sprawdzenie siły i wzajemności wyboru uzyskanego dla hasła sosna w badaniu pilotażowym przeprowadzonym w grupie 30 osób (dąb jako najsilniejsza reakcja podana przez ponad $25 \%$ grupy).

9 Podstawą wyboru hasła krowa była chęć sprawdzenia tendencji do aktywizowania podstawowej cechy płci podczas poszukiwania reakcji.

10 Założono, że hasło meduza będzie częściej interpretowane zgodnie z wiedzą potoczną, jako „nazwa stworzeń morskich o przezroczystym, galaretowatym ciele w kształcie dzwonu lub parasola”, niż jako jedna z dwóch postaci jamochłonów [por. definicje w ISJP, t. 1: 839].

11 Pozostałe hasła będą przedmiotem oddzielnych opracowań. 
podgrup i par umieszczono w różnych wersjach ankiety, w celu zmniejszenia prawdopodobieństwa ich wzajemnego wyboru (każda wersja zawierała: nazwę jednego ptaka lub ssaka i jedną z pozostałych nazw zwierząt, nazwę jednego drzewa lub kwiatu/chwastu oraz jedną z pozostałych nazw roślin, nazwę jednego mebla oraz jednego z pozostałych artefaktów ${ }^{12}$ ).

W badaniu udział wzięło 720 osób. Każda z nich otrzymała jedną z czterech wersji ankiety, zatem na hasła z jednej wersji ankiety odpowiadało w sumie 180 badanych. Grupę 720 respondentów stanowiło 548 studentów z pięciu wydziałów Uniwersytetu im. Adama Mickiewicza w Poznaniu oraz 172 uczniów liceum ogólnokształcącego i technikum, czyli osoby w wieku 16-28 lat, w tym 500 kobiet i 220 mężczyzn. Udzielenie odpowiedzi na wszystkie 25 haseł z danej wersji ankiety zajmowało badanym 10-20 minut. Badanie przeprowadzane było w grupach liczących od kilku do kilkudziesięciu osób. W każdej grupie wykorzystywano wszystkie wersje ankiet ${ }^{13}$.

Zadanie wyszukania wyrazu o znaczeniu przeciwnym w stosunku do hasel tego typu, bez wsparcia gotowego kontekstu (lub w „kontekście neutralnym” [por. Murphy 2003: $138 \mathrm{i}$ in.]) jest trudniejsze niż dla haseł dobry, życie, mąż itp., i nie można wykluczyć, że dany respondent udzieliłby innej odpowiedzi na hasło w przypadku powtórzenia badania. Podstawą formułowania wniosków na temat roli kohiponimii dla pojęcia opozycji semantycznej jest zgodność interpersonalna - identyczność reakcji podawanych przez różnych respondentów i dające się uchwycić wspólne mechanizmy wyboru odpowiedzi.

\section{Wyniki}

\subsection{Analiza ilościowa: łatwość wyodrębniania opozycji semantycznej}

Otrzymano w sumie 4324 reakcje. Z możliwości udzielenia więcej niż jednej odpowiedzi skorzystało, zależnie od hasła, od 0 (dla 3 haseł) do jedynie 5 badanych osób. Oznacza to, że najczęściej reakcja wybrana przez badanego jest dla niego jedynym bądź najważniejszym kandydatem na opozycję semantyczną hasła (przynajmniej w momencie badania). Dla każdego hasła, po połączeniu reakcji identycznych uzyskanych od badanych ${ }^{14}$ wyznaczono liczbę różnych reakcji, a następnie, po uszeregowaniu odpowiedzi według częstości, wyod-

12 Hasła z większej kategorii, takiej jak RoŚLINY, ZWIERZĘTA, ARTEFAKTY, były w ankiecie oddalone od siebie, a w poszczególnych wersjach ankiety zajmowały różne miejsca.

13 Wszystkie cztery 180-osobowe podgrupy, wykonujące jedną z czterech wersji ankiety, miały podobną charakterystykę dotyczącą proporcji zarówno płci, jak i wieku oraz rodzaju i stopnia wykształcenia.

14 Jako identyczne traktowano także reakcje różniące się jedynie liczbą gramatyczną (np. krzesto/a) oraz formy podstawowe, deminutywne i augmentatywne (np. krzesło/krzesełko lub doniczka/donica). 
rębniono reakcję dominującą, zwaną dalej dominantą. Dane te, uporządkowane według siły dominanty (czyli liczby/proporcji osób, które podały taką reakcję), zawiera tabela 1 . W nawiasach przy najczęściej podawanej formie dominanty znajdują się rzadziej podawane formy wariantywne.

Podstawą wnioskowania o trudności/łatwości wyodrębniania opozycji semantycznej danego hasła mogą być następujące dane:

a) liczba osób, które nie podały żadnej reakcji,

b) wewnętrzna zgodność zbioru odpowiedzi dla danego hasła, wyznaczona przez liczbę reakcji różnych oraz przez siłę dominanty.

Biorąc pod uwagę wskaźnik braku reakcji (druga kolumna tabeli), zadanie okazało się szczególnie trudne dla haseł popielniczka (8 osób nie podało odpowiedzi) oraz taca (5 osób), a najłatwiejsze dla sosna, żótw, krowa (wszyscy badani podali reakcję). Zgodność interpersonalna grupy mierzona siłą dominanty (liczby/proporcji osób podających tę odpowiedź) w zasadzie zmniejsza się stopniowo (por. przedostatnia kolumna), wskaźnik ten nie pozwala zatem na wyraźne pogrupowanie zbioru haseł. Ustawienie przykładowych arbitralnych granic: ponad $25 \%$ i poniżej $10 \%$ badanych, wskazuje hasła wróbel, żótw, krowa, sosna i łóżko jako znacznie „łatwiejsze” niż pingwin i popielniczka. Natomiast największą zgodność mierzoną liczbą różnych reakcji uzyskano dla hasła fotel (tylko 48 różnych odpowiedzi), a zdecydowanie najmniejszą dla haseł popielniczka i fiołek (około 100) ${ }^{15}$. Wśród tych grup haseł „łatwych” i „trudnych” wyróżnia się jedno: wszystkie trzy wskaźniki sugerują trudność znalezienia opozycji semantycznej dla rzeczownika popielniczka.

Wskaźnikiem wspomagającym ocenę łatwości znajdowania opozycji dla hasła, a zarazem ukazującym rolę reakcji dominującej jest różnica między jej siłą a siłą reakcji drugiej co do częstości występowania (ranga II). Dla 16 haseł, w tym dla 6 nazw roślin, 6 nazw zwierząt i 4 nazw artefaktów różnica ta wynosi minimum 5\% (czyli reakcję drugą co do częstości podało co najmniej o 9 osób mniej niż dominantę) ${ }^{16}$. Natomiast dla pozostałych 8 haseł (popielniczka, taca, wazon, szafa, pokrzywa, paproć, ropucha i pingwin) różnica między siłą reakcji najczęstszej i o randze II nie jest wyraźna, nie osiąga 5\%.

15 Wskaźniki siły dominanty i liczby różnych reakcji potencjalnie korelują ze sobą (mimo iż możliwy jest układ typu: silna reakcja dominująca i stosunkowo dużo bardzo słabych).

16 Różnica ta wzrasta do $15 \%$ lub więcej dla hasel: krowa, żyto, tóżko, kapusta, żótw, sosna, wróbel, w tym dla tych trzech ostatnich osiąga powyżej $20 \%$. 
Tabela 1. Brak reakcji, liczba reakcji różnych i dominanta

\begin{tabular}{|c|c|c|c|c|c|}
\hline Hasło & $\begin{array}{c}\text { Brak } \\
\text { reakcji } \\
\text { (liczba } \\
\text { osób) }\end{array}$ & $\begin{array}{l}\text { Liczba } \\
\text { różnych } \\
\text { reakcji }\end{array}$ & reakcja & $\begin{array}{c}\text { liczba } \\
\text { osób }\end{array}$ & $\begin{array}{c}\% \\
\text { grupy }\end{array}$ \\
\hline wróbel & 3 & 55 & orzeł & 63 & 35,0 \\
\hline lóżko & 1 & 59 & podłoga & 61 & 33,9 \\
\hline sosna & 0 & 54 & dąb & 60 & 33,3 \\
\hline żólw & 0 & 63 & gepard & 54 & 30,0 \\
\hline krowa & 0 & 71 & byk & 47 & 26,1 \\
\hline kapusta & 1 & 68 & sałata & 41 & 22,8 \\
\hline żyto & 3 & 73 & pszenica & 41 & 22,8 \\
\hline fotel & 1 & 48 & krzesło(a) (krzesełko) & 39 & 21,7 \\
\hline pszczoła & 3 & 55 & osa & 38 & 21,1 \\
\hline półka & 2 & 54 & szafa (szafka) & 34 & 18,9 \\
\hline zebra & 1 & 71 & koń & 33 & 18,3 \\
\hline dąb & 1 & 86 & sosna & 32 & 17,8 \\
\hline ropucha & 1 & 52 & żaba (żabka, żabcia) & 31 & 17,2 \\
\hline meduza & 2 & 92 & ryba & 26 & 14,4 \\
\hline szkatułka & 1 & 73 & pudło (pudełko, pudełeczko) & 25 & 13,9 \\
\hline taca & 5 & 69 & miska (misa) & 24 & 13,3 \\
\hline mech & 3 & 81 & trawa & 23 & 12,8 \\
\hline pokrzywa & 2 & 63 & kwiat (kwiatek) & 21 & 11,7 \\
\hline fiołek & 3 & 99 & róża & 20 & 11,1 \\
\hline paproć & 2 & 80 & kaktus, róża & 19 & 10,55 \\
\hline wazon & 1 & 75 & doniczka (donica) & 18 & 10,0 \\
\hline szafa & 1 & 59 & półka (półeczka) & 18 & 10,0 \\
\hline pingwin & 2 & 85 & lew & 15 & 8,3 \\
\hline popielniczka & 8 & 101 & papieros(y) & 15 & 8,3 \\
\hline
\end{tabular}




\subsection{Analiza jakościowa: podstawowe mechanizmy wyboru reakcji}

Analiza jakościowa otrzymanych reakcji polegała na próbie określenia ich semantycznego związku z hasłem, który mógł stać się podstawą wyboru w badaniu. Punktem wyjścia analizy jest odpowiedź na pytanie, czy hasło i reakcję można traktować jako kohiponimy, przez zaproponowanie najbliższego wspólnego dla nich hiperonimu bądź rozbudowanego wyrażenia o szerszym, wspólnym dla nich zakresie (para wyodrębniona ze zbioru wieloelementowego z założenia nie ma najbliższego zleksykalizowanego hiperonimu wspólnego tylko dla jej członów). Jako kryterium graniczne sensowności traktowania bodźca i reakcji jako kohiponimów przyjmuje się arbitralnie następujące najszersze hiperonimy (zależnie od kategorii hasła): ZWIERZE, ROŚLINA, MEBEL, POJEMNIK/NACZYNIE, tj. np. jeśli dla hasła denotującego organizm zwierzęcy pojawiła się reakcja stanowiąca nazwę innego (dowolnego) zwierzęcia, została zakwalifikowana jako kohiponim hasła. Rozbudowane określenia hiperonimiczne należy traktować jako robocze i z założenia potoczne (nawiązujące do systematyki naukowej jedynie w zakresie znanym przeciętnemu użytkownikowi języka). Podstawę analiz i sformułowań stanowią m.in. definicje z ISJP (2000).

\subsubsection{Rola kohiponimii jako podstawy poszukiwania opozycji}

\section{Kohiponimia w reakcjach dominujących}

Poniżej przedstawione zostaną robocze (możliwie najwęższe znaczeniowo) wyrażenia o wspólnym zakresie dla hasła i dominanty zakwalifikowanej jako kohiponim hasła.

\section{Kategoria ZWIERZĄT}

wróbel - orzel: ptak latający, żyjący w naszym ${ }^{17}$ klimacie żótw - gepard: kręgowiec krowa - byk: popularny ${ }^{18}$ przedstawiciel bydła domowego pszczoła - osa: popularny owad latający, w paski ciemne i żółte, z żądłem zebra - koń: ssak czworonożny z kopytami, z podłużną głową, grzywą i ogonem z długich włosów

17 Wyrażenie nasz klimat, zrelatywizowane do miejsca badania i grupy respondentów, stosowano w celu uproszczenia złożonych określeń.

18 Wyrażenie popularny w odniesieniu do roślin i zwierząt oznacza tutaj „taki, który z powodu powszechności występowania potencjalnie jest znany wielu ludziom, zwłaszcza mieszkającym na obszarze jego występowania”. 
ropucha - zaba: płaz wodno-lądowy, bez szyi i ogona, o dużej głowie i wyłupiastych oczach, skaczący

meduza - ryba: zwierzę wodne

pingwin - lew: kręgowiec

\section{Kategoria ROŚLIN}

sosna - dąb: popularne drzewo rosnące w naszym klimacie

kapusta - sałata: popularne warzywo o liściach tworzących dużą kulę

żyto - pszenica: popularne zboże, z nasionami tworzącymi pojedynczy kłos

$d a b$ - sosna: popularne drzewo rosnące w naszym klimacie

mech - trawa: popularne drobne, cienkie, zielone rośliny rosnące w skupi-

skach, kępach

pokrzywa - kwiat: niewielka roślina z niezdrewniałą łodygą, z której wyrastają

liście

fiołek-róża: popularny kwiat

paproć-kaktus: niewysoka (w naszym klimacie) roślina, niezdrewniała, zielona paproć - róża: popularna niewielka roślina, z liśćmi, rosnąca w naszym klimacie

\section{Kategoria ARTEFAKTów}

\section{MEBLE}

fotel-krzesto/krzesetko: mebel do siedzenia, z oparciem

półka - szafa/szafka: mebel do przechowywania przedmiotów, ubrań

szafa - półka/półeczka: mebel do przechowywania przedmiotów, ubrań

POJEMNIKI/NACZYNIA

szkatułka - pudło/pudełko/pudełeczko: pojemnik do przechowywania przed-

miotów, o płaskim dnie, z pokrywą

taca - miska/misa: naczynie ${ }^{19}$ niegłębokie, którego funkcja związana jest

$\mathrm{z}$ jedzeniem

wazon-doniczka/donica: naczynie do roślin, najczęściej ozdobnych

Powyższe sformułowania, choć niewątpliwe dyskusyjne, wyraźnie wskazują na bliskość znaczeniową haseł i najczęstszych reakcji. Tylko człony pary pokrzywa - kwiat pochodzą z różnych poziomów hierarchii (o ile można to rozstrzygać w odniesieniu do hierarchii potocznych): to raczej chwast, hiperonim pokrzywy jest, jak się wydaje, na jednym poziomie z kwiatem $^{20}$. Jedynie

19 Jako naczynie definiują tacę np. SJPSz 1983, t. 3: 471; SWJPDun 1996: 1118.

$20 \mathrm{~W}$ przypadku par paproć - róża i paproć - kaktus różnica poziomów taksonomii zależy $\mathrm{w}$ większym stopniu od indywidualnej wiedzy respondenta. 
dwie pary hasło-dominanta: tóżko - podłoga oraz popielniczka - papieros(y) nie znalazły się w powyższym zestawieniu, tj. nie mogą być kwalifikowane jako kohiponimy według przyjętego, dość szerokiego kryterium.

\section{Kohiponimia w całym zbiorze reakcji}

Tabela 2 przedstawia udział tych reakcji z całego otrzymanego korpusu, które można, zgodnie z przyjętym kryterium, traktować jako kohiponimy hasła. Kolumna środkowa zawiera procentowy udział reakcji zaliczonych do najszerszej „granicznej” kategorii, tj. odpowiednio do kategorii zWIERZĄT, ROŚLIN, MEBLI i POJEMNIKÓW/NACZYŃ. Natomiast w kolumnie trzeciej podano dane uszczegóławiające informacje z kolumny drugiej: udział reakcji w ważniejszych podkategoriach kategorii granicznej (jako kryterium przyjęto próg 5\% reakcji), np. dla haseł z kategorii zWIERZĘ są to podkategorie 'ptak' i 'ssak'. Podkategoria, którą reakcje dzielą z hasłem, została wytłuszczona (np. dla haseł wróbel i pingwin podkategoria 'ptak', dla zebry i krowy 'ssak' itp.). W przypadku haseł z grupy ARTEFAKTÓw rolę nazwy podkategorii kategorii granicznych pełni określenie podstawowej funkcji.

Tabela 2. Udział reakcji stanowiących kohiponimy hasła w całym korpusie odpowiedzi

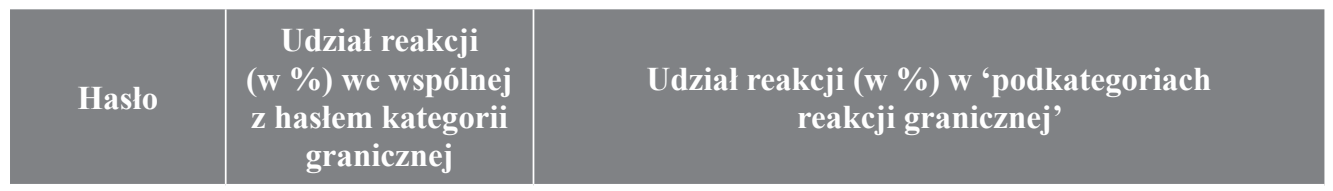

Hasła z grupy zWIERZĄT

\begin{tabular}{|c|c|c|}
\hline wróbel & ZWIERZE: 94,0 & 'ptak' 69,4; 'ssak' 15,8 \\
\hline pingwin & ZWIERZĘ: 87,2 & 'ssak' 42,2; 'ptak' 37,2 \\
\hline krowa & ZWIERZE: 88,0 & 'ssak' 65,2; 'ptak' 8,2 \\
\hline zebra & ZWIERZE: 82,0 & 'ssak' 65,6 \\
\hline$\dot{z} o ́ t w$ & ZWIERZE: 90,6 & 'ssak' 65,7; 'ptak' 12,2 \\
\hline ropucha & ZWIERZĘ: 68,0 & $\begin{array}{l}\text { 'plaz' 20,4; 'ssak' 16,0; 'ptak' } 13,3 \text {; 'gad' } 8,8 \text {; 'owad' } \\
8,3\end{array}$ \\
\hline pszczoła & ZWIERZE: 90,2 & 'owad' 61,9 ; 'ssak' 22,4 \\
\hline meduza & ZWIERZE: 72,4 & 'ryba' 26,0; 'ssak' 23,8; 'mięczak' 7,7; 'ptak' 6,1 \\
\hline
\end{tabular}




\begin{tabular}{|c|c|c|}
\hline Haslo & $\begin{array}{c}\text { Udzial reakcji } \\
\text { (w \%) we wspólnej } \\
\text { z haslem kategorii } \\
\text { granicznej }\end{array}$ & $\begin{array}{c}\text { Udzial reakcji (w \%) w 'podkategoriach } \\
\text { reakcji granicznej' }\end{array}$ \\
\hline \multicolumn{3}{|c|}{ Hasła z grupy RoŚLIN } \\
\hline sosna & ROŚLINA 85,0 & $\begin{array}{l}\text { 'drzewo liściaste' } 61,7 \text {; 'drzewo iglaste' } 11,1 \text {; 'kwiat' } \\
6,7\end{array}$ \\
\hline$d a ̨ b$ & ROŚLINA 70,9 & $\begin{array}{l}\text { 'drzewo iglaste' } 23,1 \text {; 'drzewo liściaste' 18,7; 'kwiat' } \\
13,2\end{array}$ \\
\hline fiolek & ROŚLINA 68,5 & $\begin{array}{l}\text { 'kwiat' 27,6; 'drzewo' 12,2; 'zioło/chwast'* 12,7; } \\
\text { 'kaktus' 6,1 }\end{array}$ \\
\hline pokrzywa & ROŚLINA 83,6 & 'kwiat' 38,3; 'zioło/chwast' 38,3 \\
\hline$\dot{z} y t o$ & ROŚLINA 65,2 & 'zboże' 44,8; 'trawa' 6,1 \\
\hline kapusta & ROŚLINA 72,9 & 'warzywo' 50,8; ‘owoc’ 15,4 \\
\hline paproć & ROŚLINA 77,5 & 'drzewo' 26,4; 'kwiat' 24,7; 'kaktus' 10,4; 'mech' 7,1 \\
\hline mech & ROŚLINA 34,2 & 'trawa' 12,5; 'drzewo' 8,2 \\
\hline \multicolumn{3}{|c|}{ Hasła z grupy ARTEFAKTY: MEBLE } \\
\hline szafa & MEBEL 52,2 & $\begin{array}{l}\text { 'kładzenie-przechowywanie na' } 19,8 \text {; 'siedzenie/leżenie' } \\
15,4 \text {, 'przechowywanie w' } 12,6\end{array}$ \\
\hline półka & MEBEL 51,9 & $\begin{array}{l}\text { 'przechowywanie w' } 28,2 \text {; 'kładzenie/przechowywanie } \\
\text { na' } 9,7 \text {; 'wieszanie na' } 9,7\end{array}$ \\
\hline fotel & MEBEL 62,1 & $\begin{array}{l}\text { 'siedzenie/leżenie' } 51,1 \text {; 'kładzenie/przechowywanie } \\
\text { na' } 10,4\end{array}$ \\
\hline łóżko & MEBEL 33, 1 & ‘siedzenie/leżenie' 28,7 \\
\hline \multicolumn{3}{|c|}{ Hasła z grupy ARTEFAKTY: NACZYNIA/POJEMNIKI } \\
\hline wazon & $\begin{array}{l}\text { POJEMNIK/NACZYNIE } \\
61,1\end{array}$ & $\begin{array}{l}\text { 'przechowywanie w’ (głębokie) 50,0; 'przechowywanie } \\
\text { na' (płaskie) } 11,1\end{array}$ \\
\hline taca & $\begin{array}{l}\text { POJEMNIK/NACZYNIE } \\
51,9\end{array}$ & $\begin{array}{l}\text { 'przechowywanie w' } 30,6 \text {; ' kładzenie/przechowywanie } \\
\text { na' } 15,8\end{array}$ \\
\hline szkatutka & $\begin{array}{l}\text { POJEMNIK/NACZYNIE } \\
55,2\end{array}$ & 'przechowywanie w' 54,1 \\
\hline popielniczka & $\begin{array}{l}\text { POJEMNIK/NACZYNIE } \\
29,0\end{array}$ & 'przechowywanie w' 24,0 \\
\hline
\end{tabular}

* Zdecydowano się na (pod)kategorię mieszaną 'zioło/chwast' ze względu na częściowo pokrywające się zakresy obu grup, np. do obu można zaliczyć właśnie pokrzywę, także mlecz, perz itp. 
Dla wszystkich haseł z kategorii zwIERZĄT odpowiedzi należące także do tej kategorii (a więc kohiponimy według przyjętego kryterium) stanowią ponad $2 / 3$, a dla sześciu z nich nawet ponad $4 / 5$ reakcji. Dla pięciu najsilniejsza jest ta podkategoria, którą reakcje dzielą z hasłem: dla wróbla nazwy 'ptaków', dla zebry i krowy - 'ssaków', dla ropuchy i pszczoty odpowiednio 'płazów' i 'owadów'. Natomiast dla hasła żótw reakcje z kategorii 'gad' w ogóle nie osiągnęly przyjętego progu 5\%, najczęstsza z tej grupy odpowiedź wąż została podana przez jedynie 5 osób. Przyczyną tego układu reakcji może być brak wiedzy na temat przynależności żółwi do gromady gadów (powodowany m.in. różnicami w budowie, np. brak łusek, pancerz), jednakże o dominacji podkategorii 'ssaków' w odpowiedziach decyduje cecha szybkości poruszania się: potocznie cechą wyróżniającą żółwia jest powolność (utrwalona w języku w wyrażeniach typu żótwie tempo, żótwi krok, wlec się jak żótw itp. [por. np. ISJP, t. 2: 1416]), stąd jako opozycyjne semantycznie wybierane są nazwy zwierząt postrzeganych jako najszybsze (z lądowych): gepard (dominanta), zając, struś, także lampart, tygrys, antylopa. W przypadku pingwina wysoka różnorodność reakcji i stosunkowo niska siła dominanty (por. tabela 1) wskazują brak tak silnej cechy kontrastującej. Ważną rolę odgrywa tu kontrast latanie - nielotność, wskazywany przez odpowiedzi orzel, papuga, koliber, jaskótka, bocian, ale równie istotne jest kontrastowanie pingwina, jako dużego nielotnego ptaka ze stref klimatycznych zimnych, z dużymi lądowymi czworonogami żyjącymi w klimacie gorącym, np. lew (dominanta), słoń, żyrafa, wielbład, tygrys. Hasło meduza także wywołuje reakcje różnorodne, i o niezbyt dużej sile (por. tabela 1). Najsilniejszą podkategorię stanowią 'ryby' $\mathrm{z}$ dominującą ogólną reakcją ryba oraz drugą co do częstości odpowiedzią rekin; często wybierane są nazwy zwierząt wodnych (w sumie 42,5\% korpusu odpowiedzi): ryby, morskie ssaki (np. wieloryb, delfin), mięczaki (zwłaszcza ośmiornica) i skorupiaki (np. krewetka, krab); większość z nich to zwierzęta morskie (40,3\% całego korpusu).

W przypadku prawie wszystkich haseł z kategorii RośLIN (z wyjątkiem hasła mech) reakcje należące także do tej kategorii (kohiponimy) stanowią, podobnie jak dla zwierząt, od mniej więcej $2 / 3$ do ponad $4 / 5$ reakcji, z czego dla trzech hasel - fiołek, żyto, kapusta - najsilniejsza jest ta podkategoria, którą reakcje dzielą z hasłem (odpowiednio 'kwiat', 'zboże', 'warzywo'). Dla pokrzywy reakcje z mieszanej podkategorii 'zioło/chwast' są tak samo częste, jak z podkategorii 'kwiat'. Podkategoria 'drzewo' jest niewątpliwe najsilniejsza dla sosny i dębu (odpowiednio 72,8\% i 41,8\%), podzielono ją jednak na podgrupy w celu wskazania, że sosna jest najczęściej kontrastowana z drze- 
wami liściastymi, a dąb z iglastymi ${ }^{21}$. Kontrastem dla paproci są najczęściej rośliny duże i zdrewniałe, czyli ‘drzewa' (w tym najczęściej jest to ogólna reakcja $d r z e w o)$. Jako opozycyjne traktowane są także rośliny niewielkie: kwitnące, czyli 'kwiaty' (jak róża, tulipan, pelargonia itp.) lub bez liści, ale z mięsistymi, kolczastymi łodygami, czyli 'kaktusy', oraz jeszcze mniejsze, współtworzące z paprociami runo leśne 'mchy'. Zbiór reakcji dla hasła mech, o wysokiej wewnętrznej różnorodności (wysoka liczba różnych reakcji i niska siła dominanty), zdecydowanie odbiega od pozostałych haseł z grup RośLiN i ZWIERZĄT - jedynie około 1/3 odpowiedzi mieści się w kategorii RoŚLINA, przy czym kryterium 5\% udziału osiągnęły jedynie 'trawa' i 'drzewa'. Opozycją dla wyrazu mech są zatem z jednej strony nazwy roślin podobnie jak on małych, składających się z wąskich pojedynczych elementów i rosnących w skupiskach, ale nie tak zwartych i niedających tak wyraźnego wrażenia miękkości jak kępy mchu, a z drugiej - nazwy roślin największych, kontrastujących z mchem wysokością i grubością.

W grupie ARTEFAKTów mniejszy jest udział reakcji kohiponimicznych w ustalonych dla nich kategoriach granicznych niż w grupach RośLIN i zWIERZĄT, udział ten wynosi jednak najczęściej (6 z 8 haseł) nieco ponad 50\%. Dla haseł półka i szafa podkategoria funkcjonalna, którą reakcje dzielą z hasłem, nie dominuje w reakcjach z kategorii MEBLE. Opozycję semantyczną wyrazu szafa stanowią zdaniem respondentów przede wszystkim nazwy mebli o podstawowej funkcji 'kładzenia/przechowywania na powierzchni' (jak półka, regat, stół, biurko), a także tych przeznaczonych do 'siedzenia lub leżenia' (krzesło,fotel, łóżko). Z kolei półka kontrastowana jest głównie z meblami 'z wnętrzem do przechowywana czegoś' (jak szafa, szuflada, komoda). Kontrasty wewnątrz grup o tej samej funkcji co hasło (dla szafy np. komoda, szuflada, dla półki: stól lub regat) są nieco rzadsze. Natomiast nazwy mebli podawane jako reakcje dla fotela i łóżka najczęściej dzielą z hasłami funkcję 'odpoczynku'. Fotel jest kontrastowany głównie z twardym krzesłem lub pozbawionym oparcia taboretem, a także z kanapa i łóżkiem. Dla łóżka najczęstszym kontrastem jest przeznaczone do siedzenia krzesło, rzadziej fotel, ale też miękka, służąca do siedzenia i leżenia kanapa.

Nazwy trzech obiektów o budowie wklęsłej, pozwalającej na przechowywanie określonej zawartości wewnątrz, wywołują jako reakcje przede wszyst-

21 Jak wskazują dane z tabeli 1, dąb i sosna stanowią najsilniejsze opozycje semantyczne dla siebie nawzajem, z tym że dąb jest, na poziomie interpersonalnym, prawie dwukrotnie silniejszym przeciwieństwem sosny niż odwrotnie. 
kim nazwy innych POJEMNIKów z głębokim wnętrzem. W przypadku szkatułki są to najczęściej pojemniki na różne obiekty czy materiały stałe, a więc pojemniki, które mogą mieć podobny kształt dna, dość wysokie ściany i wieko lub pokrywę (pudło, karton, skrzynia, kufer), ale także, rzadziej, pojemniki wykonane z materiału miękkiego (worek, reklamówka). Wazon kontrastowany jest albo z innym pojemnikiem do kwiatów (doniczka), albo z pojemnikami głównie na płyny (szklanka, butelka, wiadro, konewka) lub m.in. na płyny (garnek, miska, słoik). Odpowiedzi na hasło popielniczka są bardzo zróżnicowane (por. tabela 1) i reakcje z kategorii granicznej POJEMNIK/NACZYNIE są tu dużo słabsze niż dla innych haseł. Reakcje z podkategorii wyznaczonej przez funkcję 'przechowywania w' są również rozproszone, o niewielkiej sile; są to pojemniki na płyny (np. kieliszek, kubek, szklanka, wazon, akwarium) lub na obiekty bardziej zróżnicowane (np. miska). Podobne reakcje tworzą największą podkategorię POJEMNIKów w zbiorze odpowiedzi na hasło taca (hasło denotujące przedmiot płaski - na którym, a nie w którego wnętrzu znajduje się zawartość), wprowadzając wyraźny kontrast funkcji w stosunku do hasła. Dzielona z hasłem podkategoria obiektów, 'na które się coś kładzie/przenosi', jest słabsza, a zawiera reakcje typu talerz, podstawka, pótmisek, patera itp. (ale por. także paragraf następny).

Podsumowując, należy stwierdzić, że udziały reakcji kwalifikowanych tu jako kohiponimy, tj. zaliczanych do dość wyraźnie zdefiniowanych (granicznych) wspólnych kategorii z hasłem są wysokie, dla 21 haseł to ponad 50\% korpusu odpowiedzi. Pozostała część korpusów odpowiedzi stanowi materiał, którego analiza może odkryć inne sposoby i mechanizmy poszukiwania opozycji semantycznej. Najważniejsze z nich zostaną przedstawione w następnym paragrafie.

\subsubsection{Inne mechanizmy poszukiwania opozycji semantycznej}

Wiele reakcji uzyskanych od badanych można traktować jako efekt rozszerzenia mechanizmu omówionego wyżej, tj. należą one do tej samej kategorii co hasło, wprawdzie szerszej niż kategorie przyjęte uprzednio jako „graniczne” dla danego hasła, ale o wyraźnie określonych granicach. Dla haseł denotujących rośliny lub zwierzęta są to nazwy obiektów z drugiego królestwa organizmów żywych: dla zwierząt nazwy roślin (od 1 do 9 reakcji dla poszczególnych haseł), dla roślin nazwy zwierząt (od 2 do 9 reakcji). Natomiast w grupie artefaktów podstawą rozszerzenia kategorii jest najczęściej funkcja: w przypadku tóżka i fotela pojawiają się nazwy innych (tj. niebędących meblami) obiektów miękkich służących do odpoczynku (jak materac, karimata, śpiwór, dywan, poduszka), dla hasła szafa - nazwy obiektów (nie mebli), w których wnętrzu 
coś się przechowuje (np. pudło, walizka, kufer, lodówka, gablota). Z kolei jako opozycje dla szkatułki podawano nazwy mebli i pomieszczeń, w których można coś przechowywać (szafa, szuflada, komoda, skarbiec, spiżarnia), dla tacy - nazwy przedmiotów płaskich i poziomych, na których coś się kładzie (silna jest reakcja stót, podana aż przez 19 osób, pojawiły się także np. blat, lada, platforma, parapet, podium). Natomiast dla hasła wazon pojawiają się rozszerzenia w kierunku utworzenia kategorii obiektów, w/na których znajdują się kwiaty/rośliny (np. gleba, ziemia, piasek, tąka, ogród, polana).

Silnym mechanizmem poszukiwania opozycji semantycznej, widocznym w reagowaniu na nazwy artefaktów, jest także bliskość przestrzenna: obiekty denotowane przez hasło i reakcję są kontrastowane jako części pewnej tworzonej przez nie całości. Mechanizm ten wydaje się szczególnie silny w grupie MEBLI, a jego efektem jest podawanie reakcji podłoga (reakcja silna dla wszystkich 4 haseł: od 7 osób dla słowa szafa, 18 dla fotel, 24 dla pótka, do aż 61 dla tóżko - reakcja dominująca) oraz ściana (dla hasła szafa - 3 i półka - 14). Można tu zakładać dodatkowy mechanizm, uzupełniający w stosunku do opartego na bliskości (zwłaszcza dla pary łóżko - podłoga): brak denotatu hasła powoduje konieczność wykorzystywania denotatu reakcji w tej samej funkcji (spanie na podłodze). Być może takie dwa uzupełniające się mechanizmy zadecydowały o wysokiej sile tej reakcji. Natomiast w odniesieniu do grupy POJEMNIKÓW/NACZYŃ opozycje oparte na bliskości przestrzennej tworzą nazwy obiektów umieszczonych w/na przedmiocie denotowanym przez hasło. Dla hasła popielniczka jest to papieros (dominanta), także odpowiedzi słabsze: popiót i cygaro, dla wazonu to kwiaty (12 osób), dla szkatułki kilka słabszych reakcji typu biżuteria, bransoletka, pieniadz, bezcenny przedmiot. Z kolei dla tacy pojawiły się reakcje ręka (16 ) i dłoń (5), które można interpretować podobnie jak parę łóżko-podłoga: jako oparte na przyległości (taca trzymana/ niesiona $\mathrm{w}$ ręce czy dłoni) z uzupełniającym mechanizmem pełnienia funkcji przez denotat reakcji w przypadku braku denotatu hasła ${ }^{22}$.

Zbiory reakcji dla kilku haseł wskazują, że silne odzwierciedlenie w świadomości użytkowników języka pewnej cechy denotatu - jak powolność żółwia, pasy zebry, piękny zapach fiołka, parzące włoski na liściach pokrzywy, szko-

22 W przypadku hasła taca bliskość przestrzenna mogła stanowić także podstawę wyboru niektórych reakcji zakwalifikowanych wyżej jako kohiponimy z podkategorii NACZYNIE/POJEMNIK do 'przechowywania w' lub do 'kładzenia/przechowywania na', jak talerz, szklanka, filiżanka, kubek i kieliszek, ponieważ denotują one obiekty niesione na tacy. Nie można wykluczyć możliwości zaktywizowania u danego respondenta jednego z dwóch mechanizmów (poszukiwania elementu z tej samej kategorii lub poszukiwania obiektu bliskiego przestrzennie) lub obu jednocześnie. 
dliwość palenia dla popielniczki - powoduje poszukiwanie opozycji opartej przede wszystkim na kontraście $\mathrm{z}$ tą cechą. Niekiedy skutkuje to zbiorem reakcji, które mogą zostać zakwalifikowane, według przyjętych kryteriów, jako kohiponimy, jak wymienione w paragrafie 6.2.1. liczne reakcje (w tym dominanta) dla hasła żótw, oparte na kontraście powolny vs szybki, dominanta koń dla zebry, oparta na kontraście posiadanie vs brak pasów na sierści, silna reakcja (ranga II) róża dla pokrzywy, oparta na kontraście parzące liście vs kłująca łodyga. Efektem kontrastu z wyrazistą cechą mogą być jednak również odpowiedzi pozostające poza zbiorem kohiponimów, np. odrzutowiec, sprinter lub piorun dla żótwia; pepitka, jednolity, gładki wzór, gładkość, jednobarwność dla zebry; jedwab, aksamit, plusz, wetna, poduszka dla pokrzywy. W ten sam sposób można interpretować zbiór reakcji: odchody, ekskrementy, fekalia, gnój, kat, kupa, padlina, smród, przykry zapach dla fiołka, z kontrastem piękny vs brzydki zapach, a także odpowiedzi tlen, powietrze, świeże powietrze, zdrowe płuca, zdrowie, oddech, życie dla popielniczki, oparte na kontraście związanym ze skutkami palenia papierosów (zanieczyszczenie powietrza, choroba). Znamienny zbiór odpowiedzi tego typu pojawia się dla hasła ropucha: utrwalony kulturowo kontrast brzydkiej ropuchy z pięknym człowiekiem, postacią z bajki (wyrażany przez przemianę, a więc przez dwie kontrastowe formy tej samej postaci), znalazł silne odzwierciedlenie przede wszystkim w odpowiedziach książę i księżniczka (odpowiednio II i III ranga).

\section{Podsumowanie}

Badanie potwierdziło silną psychologiczną realność opozycyjności par jednostek leksykalnych wyłonionych z wieloelementowych zbiorów kohiponimów: kontrasty znaczenia istniejące między wyrazami mającymi wspólny hiperonim są podstawą wyłaniania par o znaczeniu uznawanym przez użytkownika języka za przeciwne (przynajmniej w momencie badania). Jest to jednocześnie potwierdzenie pojmowania przez respondentów przeciwieństwa semantycznego wyrazów jako „różnicy w podobieństwie”.

Wysoki procent uzyskanych w badaniu reakcji kohiponimicznych jest, oczywiście, uwarunkowany zarówno materiałem badawczym, jak i przyjętym tu arbitralnie kryterium kwalifikowania relacji hasło - odpowiedź jako kohiponimii z hiperonimami o dość szerokich zakresach (jak zWIERZE)). Podstawą znajdowania reakcji kwalifikowanych zgodnie z kryterium jako kohiponimy są w przypadku haseł ze świata roślin i zwierząt cechy percepcyjne (np. wielkość, kolor, umaszczenie, cecha kwitnienia), geograficzno-klimatyczne oraz związek z człowiekiem i użyteczność dla niego (uprawne, hodowlane, udomowione vs dzikie), a w przypadku artefaktów funkcja oraz związane z nią cechy typu kształt czy materiał. 
O znaczeniu kohiponimii w uzyskanych wynikach świadczy też wiele przypadków przynależności bodźca i reakcji nie tylko do tej samej kategorii ogólnej, wyznaczonej przez te hiperonimy „graniczne”, ale także do podkategorii wyznaczanych przez hiperonimy o węższych zakresach (np. 'ptak'). Co więcej, niekiedy relacja między hasłem a reakcją może być ujmowana $\mathrm{w}$ terminach różnic minimalnych. Dotyczy to nawet reakcji najsilniejszych, jak: krowa-byk, zebra-koń, ropucha-żaba,fotel-krzesto, kapusta-satata, $\dot{z} y$ to - pszenica, pszczoła - osa. Pierwszy z tych przykładów, oparty na podstawowym kontraście męski - żeński, można uznać za egzemplarz zbliżający się do centrum kategorii opozycji, w pozostałych różnice dotyczą podstawowych cech percepcyjnych (odpowiednio np.: pasy; kształt ciała i brodawki; miękkość; twardość i smak liści; wygląd kłosów) bądź, w przypadku pary pszczoła-osa, wymiaru hodowany - dziki.

Za kolejny dowód roli kohiponimii w budowaniu granic kategorii opozycji można przyjąć większą trudność w znajdowaniu wyrazu o przeciwnym znaczeniu (przejawiającą się w mniejszej sile dominanty, większym rozproszeniu reakcji lub braku reakcji w ogóle) dla haseł, które nie mają, zgodnie z wiedzą potoczną, żadnych oczywistych kohiponimów, jak popielniczka.

Czynnikiem modyfikującym tendencję do poszukiwania opozycji semantycznej wśród kohiponimów hasła jest istnienie wyrazistych cech percepcyjnych, utrwalonych kulturowo, jak powolność żótwia lub brzydota ropuchy. Cecha ta staje się podstawą opozycji, powodując podawanie dalszych kohiponimów hasła (jak żótw - gepard) lub wyrazów z innych pól leksykalno-semantycznych (jak odrzutowiec lub piorun dla żótwia oraz książę lub księżniczka dla ropuchy).

Badanie pokazało również inny ważny mechanizm poszukiwania opozycji przez respondentów, oparty na fizycznej „przyległości” denotatów dwóch wyrazów. O sile tego mechanizmu świadczy wykorzystywanie go także w przypadku tych haseł, dla których istnieją kohiponimy z bliskim hiperonimem wspólnym (jak łóżko). Fizyczne sąsiedztwo denotatów w jednej większej całości o charakterze przestrzennym jest na tyle istotne, że zastępuje tu połączenie podobnych i różnych cech znaczeniowych członów pary opozycyjnej, charakterystyczne dla opozycji prototypowych lub tych opartych na bliskiej kohiponimii.

Podsumowując, dane uzyskane w przedstawionym badaniu potwierdzają konieczność włączania zagadnienia kohiponimicznych zbiorów wieloelementowych do wyczerpujących, pełnych rozważań nad kategorią opozycji semantycznej. Wiedza na temat materiału budującego pogranicze tej kategorii powinna być rozwijana przez uzupełnianie rozważań językoznawczych i danych z badań korpusowych badaniami psycholingwistycznymi, z wykorzystaniem różnych technik i materiału badawczego z różnych pól leksykalnych. 


\section{Bibliografia}

\section{Skróty}

ISJP - Bańko Mirosław, red. (2000), Inny słownik języka polskiego, Wydawnictwo Naukowe PWN, Warszawa.

SJPSz - Szymczak Mieczysław, red. (1983), Słownik języka polskiego, t. 1-3, PWN, Warszawa.

SWJPDun - Dunaj Bogusław, red. (1996), Słownik współczesnego języka polskiego, Wilga, Warszawa.

\section{Literatura}

Bańczerowski Jerzy, Pogonowski Jerzy, Zgółka Tadeusz (1982), Wstęp do językoznawstwa, Wydawnictwo Naukowe UAM, Poznań.

Cacciari Cristina i in. (2015), Is black always the opposite of white? An investigation on the comprehension of antonyms in people with schizophrenia and in healthy participants, „Behavioral Sciences”, t. 5, nr 1, s. 93-112, DOI:10.3390/bs5010093.

Chaffin Roger J.S., Herrmann Douglas J. (1987), Relation element theory: a new account of the representation and processing of semantic relations, w: Memory and learning. The Ebbinghaus Centennial Conference, red. David S. Gorfein, Robert R. Hoffman, Lawrence Erlbaum Associates Publishers, Hillsdale, s. 221-245.

Cixous Hélène (1989), Sorties: Out and Out: Attacks/Ways Out/Forays, w: The Feminist Reader: Essays in Gender and the Politics of Literary Criticism, red. Catgerien Besley, Jane Moore, Macmillan, London, s. 101-116.

Cruse David Alan (1994), Prototype theory and lexical relations, ,Rivista di Linguistica", nr 6, s. 167-188.

Cruse David Alan (1995), Lexical Semantics, Cambridge University Press, Cambridge.

Cruse David Alan (2000), Meaning in language. An introduction to semantics and pragmatics, Oxford University Press, Oxford.

Cruse David Alan (2002), Hyponymy and its varieties, w: The semantics of relationships. An interdisciplinary perspective, red. Rebecca Green, Carol A. Bean, Sung Hyon Myaeng, Kluwer Academic Publishers, Dordrecht, s. 3-21.

Davies Matt (2012), A new approach to oppositions in discourse: The role of syntactic frames in the triggering of noncanonical oppositions, ,Journal of English Linguistics", t. 40, nr 1, s. 41-73, DOI: 10.1177/0075424210385206.

Grochowski Maciej (1993), Konwencje semantyczne a definiowanie wyrażeń językowych, Polskie Towarzystwo Semiotyczne, Warszawa.

Herrmann Douglas i in. (1979), Comprehension of antonymy and the generality of categorization models, „Journal of Experimental Psychology: Human Learning and Memory", nr 6, s. 585-597. 
Herrmann Douglas i in. (1986), The role of elements of relation definition in antonym and synonym comprehension, „Zeitschrift für Psychologie”, nr 194, s. 133-153.

Hurford James R. i in. (2007), Semantics. A coursebook, Cambridge University Press, Cambridge.

Jones Steven (2002), Antonymy: a corpus based perspective, Routledge, London.

Jones Steven (2006), A lexico-syntactic analysis of antonym co-occurrence in spoken English, „Text \& Talk - An Interdisciplinary Journal of Language, Discourse Communication Studies", t. 26, nr 2, s. 191-216.

Jones Steven (2007), 'Opposites' in discourse: A comparison of antonym use across four domains, „Journal of Pragmatics”, nr 39, s. 1105-1119.

Jones Steven i in. (2007), Googling for 'opposites': a web-based study of antonym canonicity, „Corpora”, nr 2, s. 129-154.

Kurcz Ida (1976), Psycholingwistyka, PWN, Warszawa.

Leech Geoffrey (1987), Semantics. The study of meaning, Penguin Books, Harmondsworth.

Lévi-Strauss Claude (2010), Surowe i gotowane, przeł. Maciej Falski, Wydawnictwo „Aletheia”, Warszawa.

Lloyd Geoffrey Ernest Richard (1966), Polarity and analogy. Two types of argumentation in early Greek thought, Cambridge University Press, Cambridge.

Lyons John (1977), Semantics, Cambridge University Press, Cambridge.

Lyons John (1984), Semantyka, t. 1, przeł. Adam Weinsberg, PWN, Warszawa.

Lobanova Anna i in. (2010), Defining antonymy: a corpus-based study of opposites by lexico-syntactic patterns, „International Journal of Lexicography”, t. 23, nr 1, s. 19-53.

Łobacz Piotra, Mikołajczak-Matyja Nawoja (2002), Skojarzenia słowne w psycholeksykologii i onomastyce psycholingwistycznej, Sorus, Poznań.

Markowski Andrzej (1986), Antonimy przymiotnikowe we współczesnej polszczyźnie na tle innych typów przeciwstawień leksykalnych, Zakład Narodowy im. Ossolińskich, Wrocław.

McNeill David (1997), Growth points cross-linguistically, w: Language and conceptualization, red. Jan Nuyts, Eric Pederson, Cambridge University Press, Cambridge, s. 190-212.

Mettinger Arthur (1994), Aspects of semantic opposition in English, Clarendon Press, Oxford.

Mikołajczak-Matyja Nawoja (2008), Hierarchiczna struktura leksykonu umysłowego. Relacje semantyczne w leksykonie widzacych i niewidomych użytkowników języka, Wydawnictwo Naukowe UAM, Poznań.

Muehleisen Victoria, Isono Maho (2009), Antonymous adjectives in Japanese discourse, „Journal of Pragmatics”, nr 41, s. 2185-2203. 
Murphy M. Lynne (2003), Semantic relations and the lexicon, Cambridge University Press, Cambridge.

Murphy M. Lynne i in. (2009), Discourse functions of antonymy: A cross-linguistic investigation of Swedish and English, ,Journal of Pragmatics”, nr 41, s. 2159-2184.

Murphy M. Lynne i in. (2015), Signals of contrastiveness: but, oppositeness, and formal similarity in parallel contexts, ,Journal of English Linguistics”, t. 43, nr 3, s. 227-249.

Okuniewska Hanna (2004), Asymetria. Antonimia. Nacechowanie. Studium psycholingwistyczne, Matrix, Warszawa.

Paradis Carita i in. (2009), Good and bad opposites. Using textual and experimental techniques to measure antonym canonicity, ,,The Mental Lexicon”, t. 4, nr 3, s. 380-429.

Paradis Carita, Willners Caroline (2011), Antonymy: From convention to meaning-making, ,Review of Cognitive Linguistics”, nr 9, s. 367-391.

Rosch Eleanor (1975), Cognitive representations of semantic categories, „Journal of Experimental Psychology: General", nr 104, s. 192-233.

Taylor John R. (2001), Kategoryzacja w języku. Prototypy w teorii językoznawczej, przeł. Anna Skucińska, Universitas, Kraków.

Van de Weijer Joost i in. (2014), Antonym canonicity: Temporal and contextual manipulations, „Brain \& Language”, nr 128, s. 1-8.

Wierzbicka Anna (1999), Język - umyst - kultura, Wydawnictwo Naukowe PWN, Warszawa.

Nawoja Mikołajczak-Matyja

\section{Co-hyponymy as a borderline relation of the category of semantic opposition. The perspective of Polish language users: psycholinguistic experiment}

The paper considers the relation of semantic opposition in terms of the prototype theory of concepts. Its purpose is to provide information on peripheral or border areas of the category of semantic opposition. Data from linguistic analyzes, as well as the results of contemporary corpus studies, indicate that pairs of co-hyponyms from multi-element sets are potentially relevant material in peripheral areas of the category of semantic opposition. A psycholinguistic study was conducted to verify the psychological reality of the data. 720 Polish language users were instructed to provide semantic oppositions to the list of 24 stimuli words (test of directed associations). The research material was Polish nouns belonging to 3 lexical fields: animals, plants and artifacts, with no obvious semantic oppositions (as bee, cabbage, vase). It turned out that, according to the hypothesis, proportions of reactions classified as co-hyponyms of stimuli are high: for 21 stimuli it was $52-94 \%$ of the response corpora and for 22 stimuli the dominant reaction 
was co-hyponym of the stimulus word (as cabbage-lettuce, bee-wasp, vase-flowerpot). The characteristics that determine the choice of a given co-hyponym as the semantic opposite of the stimulus were identified. The remainder of the response corpus was analyzed in order to reveal other ways and mechanisms for seeking the semantic opposition by respondents. The data obtained in the presented study confirm the necessity to incorporate the problem of co-hyponymic pairs from multi-element sets into reflections on the category of the semantic opposition.

KEY words: lexical semantics; psycholinguistics; semantic relations; semantic opposition; verbal association; co-hyponymy.

dr hab. Nawoja Mikołajczak-Matyja, prof. UAM - Instytut Językoznawstwa, Uniwersytet im. Adama Mickiewicza w Poznaniu; zainteresowania badawcze: semantyka, leksykologia, leksykografia, leksykalne i semantyczne aspekty psycholingwistyki, psychologia poznawcza. 
